\title{
CELE POLITYCZNE I TERYTORIALNE KRÓLESTWA CZARNOGÓRY W PRZEDEDNIU I W TRAKCIE I WOJNY BAŁKAŃSKIEJ
}

\author{
WOJCIECH SZCZEPAŃSKI
}

\begin{abstract}
Wojciech Szczepański, Cele polityczne i terytorialne Królestwa Czarnogóry w przededniu $i$ w trakcie I wojny bałkańskiej (The political and territorial objectives of the Kingdom of Montenegro on the eve of and during the First Balkan War).

Balcanica Posnaniensia. Acta et studia, XX, Poznań 2013, Wydawnictwo Instytutu Historii UAM, pp. 117-136, ISBN 978-83-63047-36-1, ISSN 0239-4278. Polish text with a summary in English.
\end{abstract}

Wojciech Szczepański, Komisja Bałkanistyki PAN/Oddziałw Poznaniu, woytasqu@o2.pl

W opracowaniach poświęconych Czarnogórze podkreśla się, że lata 1878-1912, a więc okres od formalnego, międzynarodowego uznania czarnogórskiej suwerenności na Kongresie Berlińskim ${ }^{1}$ do wybuchu I wojny bałkańskiej, stanowiły absolutnie wyjątkowy moment w dziejach tego bałkańskiego państwa. W okresie tym Czarnogóra była, bowiem, nie tylko faktycznie niepodległa i za taką oficjalnie w świecie uznawana, ale też, jeśli nie liczyć zatargów i potyczek granicznych z oddziałami albańskiej

${ }^{1}$ Rozwój Czarnogóry przed 1878 r. i jej drogę do faktycznej, a następnie międzynarodowo uznanej niepodległości, scharakteryzowano najlepiej w dwóch pracach: B. Pavićević, Sazdanje crnogorske nacionalne države 1796-1878 (Istorija Crne Gore, ured. Đ. Borozan, knj. 4, t. II), Podgorica 2004 i R. M. Raspopović, Diplomatija Crne Gore 1711-1918, Podgorica-Beograd 1996. Tekst traktatu końcowego Kongresu Berlińskiego, zawierającego m.in. uregulowania dotyczące Czarnogóry, w: Balkanski ugovorni odnosi 1876-1996. Dvostrani i višestrani međunarodni ugovori i drugi diplomatski akti o državnim granicama, političkoj $i$ vojnoj saradnji, verskim i etničkim manjinama, t. I (1876-1918), prir. M. Stojković, Beograd 1998, s. 117-162; Protocoles du Congres de Berlin, [w:] La question albanaise dans les actes internationaux de l'epoque imperialiste, t. I (1867-1912), për. A. Puto, Tirana 1985, s. 156-220. Kongresowa decyzja z 1878 r. nie oznaczała automatycznego rozstrzygnięcia wszystkich problemowych kwestii związanych z Czarnogórą. Istotna sprawa wytyczenia jej granic rozwiązywana była jeszcze po 1878 r. - zob. M. Dymarski, Rozwój terytorialny Czarnogóry w XIX i XX w., a jej położenie międzynarodowe, [w:] Centrum i peryferie Europy Środkowo-Wschodniej. Kształtowanie się terytoriów i granic państw od średniowiecza do współczesności, pod red. E. Znamierowskiej-Rakk, Warszawa 2011, s. 31-48 (szczególnie s. 40-42). 
Ligi Prizreńskiej² ${ }^{2}$ nie prowadziła wojen ${ }^{3}$. Sytuacja ta stwarzała warunki do konsolidacji państwa, a następnie jego rozwoju.

Z pewnością na docenienie zasługuje wysiłek, dzięki któremu Czarnogóra w ostatnich dwóch dziesięcioleciach XIX i pierwszym XX w. przeobrażała się w państwo stopniowo przybliżające się do standardów nowoczesności (reformy ustrojowe i administracyjne, budowa siły zbrojnej, placówek kultury, etc. ${ }^{4}$ ), a także z zaangażowaniem rozwijała relacje polityczne ze światem zewnętrznym (aktywna polityka międzynarodowa Mikołaja I Petrovicia, awans małej Cetyni do rangi dość ważnego centrum działań służb dyplomatycznych europejskich mocarstw i państw bałkańskich ${ }^{5}$ ).

W formułowanej ex post ocenie czarnogórskich dokonań z lat 1878-1912, zaznaczyć należy jednak, iż państwu temu, na skutek różnych ograniczeń, zarówno mających źródła w uwarunkowaniach wewnętrznych, jak i pochodzących z zewnątrz (polityka bałkańska Austro-Węgier! ${ }^{6}$ ), nie udało się wystarczająco dobrze wykorzystać przypadających na przełom XIX i XX w. 34 lat pokoju. Czarnogóra, prowadząca wtedy politykę ambitną ${ }^{7}$, a w niektórych kwestiach wręcz przekraczającą rzeczywiste możliwości, nie przedzierzgnęła się w tym czasie w państwo zdolne do utrzymania niezależności nawet w sytuacji kryzysu. Nie udało się jej także zachować niepośledniej roli politycznej w niestabilnym regionie. Jej potencjał nie stwarzał dostatecznych gwarancji dla podmiotowego uczestnictwa w budowie większego, jugosłowiańskiego organizmu państwowego, a więc podjęcia się roli, jaką odegrała większa i silniejsza Serbia. Ocena ta jest surowa i złagodzić można ją zapewne wątpliwościami, co do rzeczywistych możliwości czarnogórskich działań. Za jej przyjęciem przemawia jednak wzgląd na dwie niezwykle istotne kwestie: a) złą - i niewłaściwymi decyzjami Cetyni jeszcze

2 Szerzej: N. Rakočević, Crnogorsko-albanski odnosi 1878-1914. godine, [w:] Srbija i Albanci u XIX i početkom XX veka. Ciklus predavanja, 10-25. novembar 1987., ured. V. Stojančević, Beograd 1990.

${ }^{3}$ K. Morrison, Montenegro. A Modern History, London-New York 2009, s. 10; N. Rakočević, Crna Gora u Balkanskom ratu. Nacionalni, politički i ekonomski uzroci, [w:] Prvi Balkanski rat. Okrugli sto povodom 75. godišnjice 1912-1987. 28. i 29. oktobar 1987., ured. V. Stojančević, Beograd 1991, s. 17; M. Łakota-Micker, Czarnogóra. Studia nad bezpieczeństwem, Wrocław 2013, s. 37.

${ }^{4}$ F. Š́stek, Černá Hora, Praha 2007, s. 54-57, 61-63; N. Davies, Zaginione królestwa, Kraków 2010, s. 526-529; O. Myszor, L. Kolendowski, Sparta Stowiańszczyzny: Czarnogórska armia u progu Wielkiej Wojny, Militaria. Ilustrowany Magazyn Historyczny (wydanie specjalne), 6 (28)/2012, s. 46-59.

5 Zob. F. Šístek, Černá, s. 57-60; N. Rakočević, Crna Gora u balkanskom ratu, s. 17-18; U. Özcan, A. Temizer, Osmanlı'dan Cumhuriyet'e Karadağ'da Türk elçileri ve konsoloslar - The Turkish Ambassadors and Consuls in Montenegro from The Ottoman Empire to Republic, ingilizce'ye çeviren N. Eyüboğlu, Ankara 2012. Najszerszego ujęcia niniejszych kwestii dostarcza: R. M. Raspopović, Diplomatija Crne Gore, s. 314-550.

${ }^{6}$ Szerzej: Austro-Ugarska prema Srbiji i ostalim balkanskim državama, Bratstvo, br. 25, 5 X 1882, s. 1; V. Đorđević, Crna Gora i Austrija 1814-1894., Beograd 1924; H. D. Schanderl, Die Albanienpolitik Österreich-Ungarns und Italiens 1877-1908, Wiesbaden 1971; N. Rakočević, Crna Gora i Austro-Ugarska 1903-1914, Titograd 1983; V. Ćorović, Odnosi između Srbije i Austro-Ugarske u XX veku, Beograd 1992; A. Mitrović, Prodor na Balkan. Srbija u planovima Austro-Ugarske i Nemačke 1908-1918, Beograd 1981; Đ. Mikić, Austro-Ugarska i mladoturci 1908-1912, Banjaluka 1983; R. Hall, The Balkan Wars, 1912-1913. Prelude to the First World War, London 2000; M. Dymarski, Rozwój terytorialny Czarnogóry, s. 41-42.

${ }^{7}$ N. Rakočević, Crna Gora u balkanskom ratu, s. 17. 
stopniowo pogarszaną - ekonomiczną kondycję czarnogórskiego organizmu państwowego oraz b) źle prowadzoną przez Czarnogórę ,politykę jugosłowiańską” (zła ocena sytuacji politycznej, niewłaściwa hierarchizacja priorytetów i nieadekwatny do zmieniającej się sytuacji bi- i multilateralnej dobór taktyki współdziałania z Serbią).

W aspekcie ekonomicznym, 34 lata pokojowej egzystencji niepodległej Czarnogóry, przypadające pomiędzy Kongresem Berlińskim a wybuchem I wojny bałkańskiej, określić należy jako kryzysowe. Państwo czarnogórskie z wielkiego kryzysu wschodniego (1875-1878), także dzięki własnemu zwycięskiemu zaangażowaniu zbrojnemu, wyszło z poważną zdobyczą terytorialną, gdyż podwoiło ono swoje terytorium (rozrost z $4400 \mathrm{~km}^{2}$ do $\left.9335 \mathrm{~km}^{2}\right)^{8}$. Frontowe i dyplomatyczne zwycięstwa oraz poszerzenie obszaru państwa nie stały się jednak bodźcem do rozwoju gospodarczego państwa, który przełożyłby się na materialny awans społeczeństwa. Dotkliwie odczuwany był niedobór zbóż i spadek pogłowia bydła. Kryzys żywnościowy i brak perspektyw rozwojowych tak dla jednostek, jak i całego państwa, które z czasem zaczęło się coraz bardziej zadłużać, przyczyniał się do podejmowania przez wielu Czarnogórców decyzji o emigracji - głównie do sąsiedniej Serbii, większej i zasobniejszej, a także szczególnie bliskiej kulturowo oraz do Stanów Zjednoczonych ${ }^{9}$. Jak ustalił Novica Rakočević, według danych na dzień 1 V 1912 r., ok. 13 tys. czarnogórskich mężczyzn podlegających obowiązkowi wojskowemu przebywało poza granicami Królestwa z powodów zarobkowych, co odpowiadało 1/3 stanu osobowego czarnogórskiego wojska w jego rozwinięciu mobilizacyjnym ${ }^{10}$. Zadłużenie państwa, posiadającego $\mathrm{w}$ dodatku ujemny bilans handlowy, było naprawdę duże, zaś możliwości spłacania zaciągniętych zobowiązań przedstawiały się kiepsko. W 1906 r., przy rocznych wpływach budżetowych rzędu $2 \mathrm{mln}$ koron, długi Czarnogóry w samych tylko bankach austriackich sięgały kwoty 1, 5 mln koron. Poza nimi ojczyzna Mikołaja I posiadała jednak jeszcze zobowiązania dłużne względem Turcji (trzy poważane pożyczki z lat 1895-1897) i Włoch ${ }^{11}$, a z czasem także wobec Niemiec. Budżet państwa w tej sytuacji ratowano głównie subsydiami rosyjskimi ${ }^{12}$. Bezpośrednio przed wybuchem I wojny bałkańskiej Czarnogóra zagwarantowała sobie również istotne wsparcie finansowe na wydatki wojskowe, a także pomoc zbrojeniową ze strony sojuszniczej Bułgarii ${ }^{13}$. Bez tych kredytów Czarnogóra nie byłaby w stanie przystąpić u boku

8 Tamże.

${ }^{9}$ M. Dymarski, Aspekty ekonomiczne i społeczne wojen bałkańskich, Balcanica Posnaniesia. Acta et studia, t. XIX: Koegzystencja narodów i kultur na Bałkanach, pod red. I. Czamańskiej i W. Szulca, Poznań 2012, s. 223.

${ }^{10}$ N. Rakočević, Crna Gora u balkanskom ratu, s. 19. M. Dymarski podaje liczbę ok. 13,5 tys. ,mężczyzn w wieku wojskowym", przebywających na emigracji zarobkowej w momencie ogłoszenia mobilizacji poprzedzającej wybuch I wojny bałkańskiej - zob. tegoż: Aspekty ekonomiczne i społeczne, s. 224.

11 M. Dymarski, Aspekty ekonomiczne i społeczne, s. 223.

12 Tamże, s. 234 (autor informuje o kwocie 600 tys. rubli, przeznaczonych przez Rosję na wojsko królewskiej już Czarnogóry, bez podania czy zasiliły one czarnogórską kasę państwową w 1910, 1911 czy 1912 r.); S. K. Pavlowitch, Historia Bałkanów (1804-1945), Warszawa 2009, s. 216.

13 R. Rabka, Bałkany 1912-1913, Warszawa 2010, s. 41-42; J. Skowronek, M. Tanty, T. Wasilewski, Historia Stowian poludniowych i zachodnich, Warszawa 1977, s. 518-519. 
innych państw bałkańskich do przygotowań pierwszego od przeszło trzydziestu lat konfliktu zbrojnego z Turcją, jakim stała się wojna wywołana jesienią $1912 \mathrm{r}$.

Należy w tym miejscu zwrócić uwagę na to, iż do narastania problemów z wydolnością ekonomiczną państwa czarnogórskiego przyczyniała się - i to niebagatelnie - polityka prowadzona wobec niego przez jedno z państw-wierzycieli, a mianowicie Austro-Wegry. Naddunajska monarchia, przeciwna usadowieniu się Czarnogóry nad Adriatykiem, podejmowała działania uniemożliwiające zbudowanie przez to państwo własnej (choć w domyśle - finansowanej przez Rosjan) floty handlowej i marynarki wojennej (ograniczenie narzucone w Berlinie w 1878 r.). Austro-Węgrom zależało też na zobowiązaniu się władz Czarnogóry do niekorzystnego dla niej wykorzystywania dla celów handlowych wyłącznie portu w Kotorze, kontrolowanego przez Austro-Węgry (alternatywą mógłby być z powodzeniem Bar, gdyby nie rzeczone ograniczenia i naciski, dotkliwe zwłaszcza do 1909 r. $)^{14}$.

Czarnogóra - chcąca odgrywać ważną rolę na Bałkanach i aspirująca na progu $\mathrm{XX}$ w. do dalszego rozwoju terytorialnego, dążyła też do osiagnnięcia jak najlepszej pozycji politycznej w sojuszu z Serbią. Bezpośrednio przed wybuchem I wojny bałkańskiej władze czarnogórskie, a szczególnie sama czarnogórska rodzina panująca, nie cieszyły się jednak w Serbii zbyt dobrą opinią.

We właściwym zarządzaniu swoim potencjałem ekonomicznym, wątlym w stosunku do projektowanych celów, przeszkadzało Czarnogórze także i to, że jej władca Mikołaj Petrović (książę, a od 1910 r. król) wykazywał się niepospolitą skłonnością do szastania funduszami państwowymi, przeznaczając gros tychże na prowadzenie dworu i wyprawianie na nim kosztownych uroczystości. Urządzona z wielkim przepychem najważniejsza tego typu oprawa, związana była z okolicznością przyjęcia przez czarnogórskiego władcę korony królewskiej (28 VIII 1910) ${ }^{15}$. Kosztowała ona 150 tys. koron austriackich, co spowodowało spustoszenie państwowej kasy w wy-

${ }^{14}$ M. Dymarski, Rozwój terytorialny Czarnogóry, s. 41-42. W kwietniu 1909 r. państwa-sygnatariusze Kongresu Berlińskiego (1878 r.), przy aktywnej proczarnogórskiej roli Włoch, zniosły ograniczenia dla suwerenności Czarnogóry na wybrzeżu adriatyckim, obwarowując tę decyzję jednak pozostawieniem w mocy zakazu fortyfikowania Baru. W zamian za powyższe rząd czarnogórski uznał aneksję Bośni i Hercegowiny przez Austro-Węgry - H. Batowski, Państwa bałkańskie 1800-1923. Zarys historii dyplomatycznej i rozwoju terytorialnego, „Prace Polskiego Towarzystwa dla Badań Europy Wschodniej i Bliskiego Wschodu", nr XV, Kraków 1938, s. 168.

${ }^{15}$ W uroczystościach 50-lecia rządów książęcych Mikołaja i jego wyniesienia do godności królewskiej wzięli udział m.in. król Bułgarii Ferdynand, wraz z następcą tronu i dwoma ministrami. Był to ważny moment zbliżenia czarnogórsko-bułgarskiego, przygotowujący grunt pod przyszły wojenny sojusz tych państw (zob.: H. Batowski, Państwa batkańskie ..., s. 179; R. Rabka, Bałkany ..., s. 40-41). W tym samym czasie doszło do ochłodzenia w relacjach czarnogórsko-serbskich, które od kryzysu aneksyjnego $1908 \mathrm{r}$. rozwijały się pomyślnie (zob. uwagi w przyp. 22). Henryk Batowski (1907-1999) stan kontaktów czarnogórsko-serbskich z 1910 r. opisał następująco: „Na jubileuszu Mikołaja I z życzeniami nie zjawił się jego zięć, król [Serbii] Piotr, lecz następca tronu, ks[iążę] Aleksander, a więc wnuk króla Mikołaja. Przyjęcie tytułu królewskiego przez starego władcę Czarnogóry spotkało się z żywym niezadowoleniem w Serbii. [...] Zawiść i nieufność między obu dynastiami serbskimi przybierała na sile m.in. dlatego, że fakt zacieśnienia stosunków serbsko-rosyjskich [...] po części osłabiał dotychczasową bardzo mocną pozycję 
miarze sięgającym rocznych wydatków Czarnogóry na edukację ${ }^{16}$ oraz ok. 3/4 rocznych wydatków czarnogórskiego Ministerstwa Wojny ${ }^{17}$. Kwoty tego rzędu można było z pewnością przeznaczyć chociażby na dozbrojenie czarnogórskiej armii. Legendarna bitność czarnogórskich żołnierzy, nie mogła wszakże stanowić wystarczającego oręża $\mathrm{w}$ ewentualnej konfrontacji z przeciwnikiem dysponującym siłami większymi i lepiej uzbrojonymi ${ }^{18}$.

Oprócz wątłych podstaw ekonomicznych do prowadzenia wojny 1912 r., krytycznie, jak już to zasygnalizowano, oceniać należałoby przedwojenną i wojenną czarnogórską strategię polityczną. W jej projektowaniu znacznie oddalono się od zasady „mierzenia sił na zamiary”. Siły Czarnogóry, określanej niekiedy w literaturze przedmiotu mianem państewka nie tylko miniaturowego, ale i wręcz „operetkowego"19, jak już wskazano wyżej, były nieznaczne. W twardym rachunku, w którym liczyły się po pierwsze środki finansowe, jakie udało się na wojenne potrzeby wygospodarować (a może raczej należałoby rzec „zorganizować”, uwzględniając fakt, iż Czarnogóra nie była w tym względzie samowystarczalna, lecz zapożyczała się), a po drugie liczebność formacji zbrojnych oraz jakość posiadanych przez nie środków bojowych czarnogórską kartę stanowiło 103 mln franków (wydatki poniesione bezpośrednio na I wojnę bałkańską) oraz ok. 35600 żołnierzy (faktycznie zmobilizowanych do udziału w I wojnie bałkańskiej z 40000 planowanych ${ }^{20}$. W aspekcie, który już aż tak wymierny nie jest, atutem Czarnogóry, którą jej ambitny król „chciał widzieć wielką”, miały być szersze sojusze - z Rosją (wymiar dyplomatyczno-międzynarodowy, fundusze dla wojska) ${ }^{21}$ i z Serbią (podpisany w $1908 \mathrm{r}^{22}$ ) oraz z pozostałymi państwa-

króla Mikołaja w Petersburgu. Doszło do tego więc, iż Czarnogóra najpierw zawarła sojusz antyturecki z Bułgarią [...]" - H. Batowski, Państwa bałkańskie..., s. 179-180.

${ }_{16}$ M. Dymarski, Aspekty ekonomiczne i spoleczne, s. 223-224.

17 „W pierwszej dekadzie XX w. na potrzeby Ministerstwa Wojny przeznaczano [w Czarnogórze W.S.] regularnie 6-8\% wydatków budżetowych państwa. W 1906 r. było to 200000 koron austriackich. Potrzeby obronne miały zatem dość niską pozycję w budżecie państwa (aczkolwiek zapewne było to realistycznie umotywowane), gdyż w tym samym okresie wydatki wojskowe pobliskiej Grecji wynosily ok. 15\%, a w Serbii aż 25\%.” - O. Myszor, L. Kolendowski, Sparta Stowiańszczyzny, s. 47.

${ }^{18}$ Charakterystyka ówczesnego stanu sił zbrojnych Królestwa Czarnogóry: tamże, s. 46-59; R. Rabka, Batkany, s. 70-72; T. Rawski, Państwa Europy Poludniowo-Wschodniej i ich armie podczas wojen batkańskich w latach 1912-1913, [w:] Państwa narodowe Europy Środkowo-Wschodniej w XX wie$k u$, red. W. Balcerak, Łowicz-Warszawa 2000, s. 82. W ostatniej z cytowanych prac (s. 82-83) - również pobieżna charakterystyka sił zbrojnych pozostałych państw bałkańskich oraz ich przeciwnika - Turcji.

${ }^{19}$ K. Stępnik, Wojny batkańskie lat 1912-1913 w prasie polskiej. Korespondencje wojenne i komentarze polityczne. Lublin 2011, s. 11.

${ }^{20}$ M. Dymarski, Aspekty ekonomiczne i społeczne, s. 228 i 226.

${ }^{21}$ Czarnogórsko-rosyjska konwencja wojskowa podpisana została w 1910 r. Jej omówienie: R. M. Raspopović, Diplomatija Crne Gore, s. 515-521.

${ }^{22}$ W październiku 1908 r., po aneksji Bośni i Hercegowiny przez Austro-Węgry doszło do ponownego nawiązania stosunków dyplomatycznych przez Czarnogórę i Serbię, poróżnione wcześniej na tle tzw. afery bombowej w Czarnogórze, o której sprawstwo posądzano w Cetyni Serbię. Wznowienie relacji dwustronnych przypieczętowano zawarciem 24 X 1908 r. czarnogórsko-serbskiej konwencji wojskowej wymierzonej w Austro-Węgry - M. Dymarski, Konflikty na Bałkanach w okresie ksztaltowania się państw narodowych w XIX i na poczqtku XX wieku, Wrocław 2010, s. 236. 
mi bałkańskimi, organizującymi się przeciw Turcji (porozumienia z Bułgarią, Grecją oraz Serbią, regulujące konkretnie kwestie przygotowań wojennych ${ }^{23}$ ).

Nie lekceważąc wojennych układów państwa Mikołaja I z pozostałymi sprzymierzeńcami z sojuszu bałkańskiego (szczególnie z Bułgaria), podkreślić należy, iż porozumienie z Serbią posiadało kluczowe znaczenie dla ostatecznego sprecyzowania przez Czarnogórę celów politycznych i terytorialnych, które chciała ona osiągnąc w wojnie z Turcją oraz dla opracowania konkretnej taktyki planowanych działań zbrojnych. Osiagnięto je właściwie w ostatniej chwili przed wybuchem I wojny bałkańskiej, bowiem rokowania dwustronne w Lucernie zakończone zostały 1 X 1912 r., zaś do podpisania konwencji politycznej i wojskowej doszło w Cetyni 6 X 1912 r. ${ }^{24}$ Pierwsza z owych konwencji dotyczyła planu powojennego podziału terytorium Sandżaku Nowopazarskiego na części czarnogórską i serbską, w drugiej natomiast zaprojektowane zostały wspólne przedsięwzięcia zbrojne układających się stron na tym obszarze oraz na części ziem albańskich ${ }^{25}$.

W czarnogórskim planie operacyjnym z 3 X 1912 r., za pierwszorzędny cel uznano działania mające zapewnić opanowanie Szkodry, do czego zaangażowano Oddziały: Zetski (liczący ok. 15 tys. żołnierzy, powierzony dowództwu następcy tronu księcia Daniły, którego wspierał dowódca sztabu komandir Jovo Bećir) oraz Nadmorski (w sile 8 tys. żołnierzy, pod wodzą brygadira Mitara Martinovicia) - mające prowadzić natarcie po obu brzegach Jeziora Szkoderskiego. W strukturze czarnogórskich sił zbrojnych działał ponadto Odział Wschodni, którym dowodził serdar Janko Vukotić (1866-1927), liczebnością zbliżony do Oddziału Nadmorskiego. Miał on nie tylko osłaniać siły rzucane na Szkodrę, ale też operować w regionie Sandżaku Nowopazarskiego i Metochii ${ }^{26}$.

${ }^{23}$ Tamże, s. 233-245; R. Rabka, Bałkany, s. 32-42; R. M. Raspopović, Diplomatija Crne Gore, s. 529-550 (szczegółowe omówienie układów Czarnogóry z Serbią oraz z Bułgarią). W historiografii polskiej, mimo nie dysponowania pełnym spektrum źródeł, dość wnikliwej analizy procesu zawiązania się antytureckiego sojuszu bałkańskiego w 1912 r. dostarczył również H. Batowski - autor dwóch, klasycznych już, opracowań ujmujących ten temat: H. Batowski, Państwa batkańskie (szczególnie s. 178-188): tenże, Podstawy sojuszu bałkańskiego 1912 r.: studium z historii dyplomatycznej, „Prace Polskiego Towarzystwa dla Badań Europy Wschodniej i Bliskiego Wschodu”, nr XVIII, Kraków 1939.

${ }^{24}$ T. Rawski, Państwa, s. 81. R. Rabka podaje, iż ratyfikacja przez Serbię rzeczonego porozumienia, wynegocjowanego w szwajcarskiej Lucernie i podpisanego w Cetyni, nastapiła 15 X $1912 \mathrm{r}$. (R. Rabka, Bałkany, s. 42), a więc już w trakcie prowadzenia przez Czarnogórę działań wojennych przeciwko Turcji.

${ }^{25}$ M.Tanty,Terytorialneaspiracjeuczestnikówwojenbałkańskich,[w:]Centrumiperyferie, s. 99. Warto przypomnieć w tym miejscu, że kontrolowany do 1908 r. przez Turcję obszar Sandżaku Nowopazarskiego znalazł się pod okupacją austrowęgierską, w związku z zaanektowaniem przez monarchię habsburską Bośni iHercegowiny.Jużjednak26II 1909r.Austro-WęgryzawarływStambuleukładzTurcją, namocyktóregozrzekły się prawa do okupowania regionu, Turcja zaś uznała porządki austrowęgierskie w Bośni i Hercegowinie, wzamianzaróżnegwarancjeWiedniadlaludnościmuzułmańskiej,zamieszkującejzaanektowaneterytorium, a także stosowne rekompensaty pieniężne oraz inne ustępstwa (natury gospodarczej i prestiżowej) względem Turcji - H. Batowski, Państwa bałkańskie, s. 166-167.

${ }^{26}$ T. Rawski, Państwa, s. 82. 
Na mocy porozumień z sojusznikami Czarnogóra pierwsza wydała wojnę Turcji (8 X 1913 r. $)^{27}$. Podjęte przez Czarnogórę akcje zaczepne - jak podkreślili to w opracowaniach dotyczących tego zagadnienia m.in. S. Drljević i H. Batowski - miały na celu przede wszystkim odciągnąć część sił tureckich z Tracji, co służyło ułatwieniu zadań ofensywnych Serbom i Bułgarom (wraz z Grekami przystapili oni do wojny z Turcją półtora tygodnia po Czarnogórze $)^{28}$.

Działania zaplanowane przez Serbów zakładały z kolei przede wszystkim, analizowane w historiografii serbskiej najdokładniej, frontalne uderzenie najliczniejszą 1. armią, skoncentrowaną w okolicy Vranja, na Kumanovo i Owcze Pole (gdzie spodziewano się zaciekłego oporu sił tureckich) oraz operacje w Kosowie i na terytorium Macedonii Wardarskiej. W strategii serbskiej, oprócz planu podporządkowania sobie Kosowa i jak największej części drugiego z wymienionych tu obszarów, do którego pretensje, uzasadniane historycznie i etnograficznie, rościli sobie również Bułgarzy, istotne znaczenie przypisano również operacjom ukierunkowanym na Sandżak Nowopazarski i Metochię, a także na północno- oraz środkowoalbańskie wybrzeże Morza Adriatyckiego. Z okolic miejscowości Raszka, przez Nowy Pazar, na Kosowską Mitrowicę przesuwać miały się Wojska Ibarskie gen. Mihailo Živkovicia. Do Sandżaku Nowopazarskiego wkroczyć miała Brygada Javorska ppłk. Milivoja Anđelkovicia. Przedłużenie ofensywy z Kosowa w kierunku Adriatyku, a więc działania na terytorium rdzennie albańskim, powierzono natomiast 3. armii gen. Božidara Jankovicia. Uprzedzając dalsze wywody, w których zahaczy się jeszcze o kwestię ówczesnego rozgraniczenia stref interesów Serbii i Czarnogóry, już w tym miejscu wspomnieć można, że działania tej armii doprowadziły 4 XI 1912 r. do zajęcia przez Serbów miasta Đakovica w Metochii. Następnie Serbom, po formalnym wstrzymaniu przez nich natarcia $\mathrm{w}$ kierunku morza, co nastapiło $\mathrm{w}$ efekcie protestu mocarstw sprzeciwiających się zajmowaniu przez Serbię ziem albańskich, udało się w dniach 9-18 XI 1912 r. opanować akcjami zaczepnymi lotnych oddziałów, wyodrębnionych z 3. armii, cele na wybrzeżu Adriatyku, w tym portowe miasta Leża (alb. Lezhë) i Durrës ${ }^{29}$.

Powyższe zestawienie wyznaczanych celów i podporządkowanych ich realizacji zamierzeń taktyczno-bojowych pokazuje, że plany, skonstruowane przez związanych sojuszem Serbów i Czarnogórców, które uznać można by w sumie za komplementarne, zawierały w sobie mimo wszystko pewne zarzewie konfliktu. Mógł on zaistnieć między sprzymierzeńcami w związku z niesprecyzowaną wówczas jeszcze do koń-

\footnotetext{
${ }^{27}$ M.-Ž. Čalić [M.-J. Calic], Istorija Jugoslavije u XX veku, Beograd 2013, s. 81; M. Tanty, Terytorialne aspiracje, s. 99.

${ }^{28}$ H. Batowski, Państwa bałkańskie, s. 188-189 (o informacjach S. Drljevicia z pracy tegoż pt. Na kapiji balkanskog saveza, Zagreb 1937, wzmianka za cytowanym tu opracowaniem H. Batowskiego).

${ }^{29}$ T. Rawski, Państwa, s. 85-86. Cenna relacja źródłowa nt. walk toczonych przez siły serbskie na terytorium albańskim: J. Tomić, Rat u Albaniji i oko Skadra 1912. i 1913. godine, Niš 1988, s. 86 (reprint wyd. Novi Sad 1913). Zob. również: V. Šćepanjski [W. Szczepański], Albanci u izveštajima Jaše Tomića iz prvog svetskog rata (1912/1913), [u:] Prvi balkanski rat 1912/1913. godine. Društveni i civilizacijski smisao. (Povodom stogodišnjice oslobođenja Stare Srbije i Makedonije), ured. A. Rastović, Niš 2013, s. 517-525.
} 
ca, a tym samym ostatecznie przez rządzących w Belgradzie i Cetyni nieuzgodnioną, koncepcją współdziałania na rzecz przyszłej budowy wspólnego jugosłowiańskiego państwa. Istniejący stan rzeczy powodował, że w ówczesnych działaniach politycznych przywódców Czarnogórców i Serbów całkiem wyraźnie zaznaczał swoją obecność duch rywalizacji.

Pewną ambiwalencję postaw, polegającą na równoczesnym opowiadaniu się za kooperacją z Serbią oraz za współzawodnictwem z nią, nietrudno dostrzec zreszta w obliczu, jakie posiadały idee i działania, głoszone i podejmowane, przez Mikołaja I. Czarnogórski król, był sukcesorem tradycji czarnogórskiego jugoslawizmu, wykoncypowanego m.in. przez jego wielkich poprzedników księcia Piotra II i księcia Daniłę II Petroviciów - Njegošów ${ }^{30}$. Jako władca niezwykle ambitny uznawał on samego siebie, niejako na przekór rzeczywistemu potencjałowi państwa, nad którym panował, za godnego pretendenta do odegrania głównej roli w jugosłowiańskim procesie zjednoczeniowym. Nadto, niejednokrotnie zajmowaną przez siebie postawą, Mikołaj I zdawał się i własnym poddanym, i Serbom, a nawet innym europejskim władcom, iż to właśnie on, jak nikt inny, posiada moralne i intelektualne przymioty, predestynujące go nawet do stanięcia na czele przyszłego królestwa „Jugosłowian”, mającego odnowić dziedzictwo nemanjiciowskie i złączyć w polityczną jednię Czarnogórców, Serbów i południowosłowiańskich poddanych Habsburgów ${ }^{31}$. Ewentualne ustępstwo Mikołaja I w tej kwestii na rzecz serbskich Karađorđeviciów umożliwić mogły zatem jedynie względy ekstraordynaryjne, ale nawet zaakceptowanie tychże nie mogło pozbawiać króla Czarnogóry jakiejś pozycji uprawniającej go do odgrywania szczególnej roli w przyszłym państwie, współtworzonym z Serbią. Mikołaj I z całą pewnością zarówno w przededniu I wojny bałkańskiej, jak i w latach późniejszych, tak długo jak tylko posiadał rzeczywisty wpływ na sytuację w Czarnogórze (umownie wskazać można tu na styczeń 1916 r. i udanie się wówczas na emigrację, jako moment utraty tego wpływu, mimo nadal podejmowanych starań zachowania go ${ }^{32}$ ), usiłował prowadzić politykę czarnogórską, jako „politykę wielkiego celu”. Za cel ów Mikołaj I nie uznawał odseparowania Czarnogóry od głównego nurtu wydarzeń przeobrażających oblicze Bałkanów i realizacji koncepcji li tylko wielkoczarnogórskiej ${ }^{33}$. Zamierzał on

${ }^{30}$ A. Giza, Jugoslawizm władców Czarnogóry w pierwszej połowie XIX w., „Przegląd Zachodniopomorski", t. 4, 1991, s. 23-38.

31 W okresie od 1908 aż do 1918 r., a więc od aneksji Bośni i Hercegowiny przez Austro-Węry do wyłonienia się nowego porządku na mapie politycznej Europy po I wojnie światowej, ,[...] pod berłem Habsburgów znajdował się obszar ziem jugosłowiańskich, wynoszący ok. 154 tys. km²" - H. Batowski, Państwa balkańskie..., s. 168.

32 Por. kolekcję dokumentów zawartą w publikacji: Uloga Francuske u nasilnoj aneksiji Crne Gore (zvanična dokumenta, koja objavljuje Ministarstvo spoljnih poslova Kraljevine Crne Gore), prir. Š. Rastoder, prev. M. Vukićević, Bar-Podgorica 2000 oraz zamieszczony w niej tekst Š. Rastodera (riječ priređivača) pt. Politika svršenog čina (s. 199-235).

33 Idea, którą określić można by mianem wielkoczarnogórskiej sensu stricte, wywoływała w rzeczywistości w samej Czarnogórze nikły rezonans, pozostając w cieniu konceptu jugoslawizmu - D. Wybranowski, Między niepodległościa a dezintegracja. Bośnia i Hercegowina w XX i XXI wieku, Szczecin 2011, s. 57. 
raczej dążyć do wzmocnienia państwa czarnogórskiego przez poszerzenie jego terytorium, spodziewając się iż dzięki temu uzyska ono możliwość skutecznego wywierania wpływu na kształt krystalizującego się ,projektu jugosłowiańskiego”. Okazało się, iż w prowadzonej przez siebie grze politycznej władca Czarnogóry popełniał jednak poważne błędy, a niektóre z podejmowanych przezeń inicjatyw okazały się zdecydowanie przeszarżowane; szczególnie w kontekście dość jednoznacznego postawienia przez Rosję na Serbię, jako główne centrum koordynacyjne zjednoczeniowego ruchu/projektu jugosłowiańskiego, do czego doszło jeszcze w okresie formowania się sojuszu bałkańskiego (co najmniej na kilka miesięcy przed wybuchem I wojny bałkańskiej) $)^{34}$.

Jak już wskazano wyżej, głównym celem czarnogórskiej strategii wojennej, a co za tym idzie również pierwszoplanowym obszarem działań wojskowych przeprowadzanych dla jego realizacji, stało się miasto Szkodra wraz z najbliższą okolicą. W ocenie N. Rakočevicia, na decyzję króla Mikołaja I o, prowadzonej „do upadłego”, walce o panowanie nad Szkodra, wpłynęły argumenty historyczne oraz wzgląd na czarnogórski, narodowy interes polityczny ${ }^{35}$. W XI w. Szkodra była stolicą Zety. W propagandzie czarnogórskiej sprzed wybuchu I wojny bałkańskiej stwierdzano jasno, że ogłoszenie państwa Petroviciów - Njegošów w 1910 r. królestwem, stanowiło wskrzeszenie tego średniowiecznego południowosłowiańskiego państwa. Również średniowieczna przynależność Szkodry do serbskiego carstwa Nemanjiciów, pełniącej w nim reprezentacyjną funkcję siedziby następcy tronu, jak też pamięć o toczonych pod Szkodrą w XV w. walkach z Turkami i Wenecjanami - były dyskontowane w polityce Czarnogóry, jakoby posiadającej prawo do rządów nad tym północno-albańskim miastem, jego okolica, a nawet całą położoną na północ od rzeki Mati częścią tureckiego wilajetu szkoderskiego (zamieszkiwaną niemal wyłącznie przez Albańczyków i Turków).

Argumenty historyczne i polityczno-propagandowe, wsparte uzasadnieniami ekonomicznymi i strategicznymi ${ }^{36}$, a także kalkulacją na określony efekt, jaki zamierzano wywołać w sprzymierzonej Serbii zdobyciem Szkodry i jej okolicy (w tym usytuowanego w pobliżu miasta fragmentu północno-albańskiego wybrzeża morskiego z portem Shëngjin ${ }^{37}$ ), usuwały w cień prawdę o absolutnym braku przesłanek etnograficznych, które mogłoby uzasadniać ewentualne wcielenie zdobytego terytorium do Czarnogóry i jego pomyślną integrację z tym państwem ${ }^{38}$. W Cetyni nie liczono się też zbytnio z tym, jaka będzie reakcja mocarstw na próbę ustanowienia czarnogórskiego władztwa nad Szkodrą i okolicą, mimo iż czarnogórscy włodarze musieli na bieżąco zauważać okazywaną przez wielu dyplomatów niechęć do czarnogór-

${ }^{34}$ M.-Ž. Čalić, Istorija Jugoslavije, s. 81.

${ }^{35}$ N. Rakočević, Crna Gora u balkanskom ratu, s. 19.

36 Tamże, s. 20.

${ }^{37}$ Miasto to Czarnogórcy nazywali Sveti Ivan (Jovan) Meduanski. W literaturze często operuje się też jego włoską nazwą San Giovanni di Medua.

38 Już w ostatniej ćwierci XIX w. Szkodra posiadała wybitnie albański charakter, o czym pisano także w Czarnogórze, zob.: T. P. O., Vijesti iz Skadra, Glas Crnogorca, br. 22, 16 VI 1879, s. 2. 
skiej, a także serbskiej, ekspansji na terytorium rdzennie albańskie ${ }^{39}$, a dodatkowo - wciąż świeżymi były doświadczenia, wyniesione przez Czarnogórców z zatargów z Albańczykami i Turkami o Ulcinj ${ }^{40}$. Szkodra pozostawała jednak, mimo wszystkich zastrzeżeń i całego ryzyka, jakie wiązało się z forsowaniem planu jej zdobycia i wcielenia do Czarnogóry, kluczowym elementem czarnogórskiego „snu o potędze”. Paralele z toczoną u schyłku lat siedemdziesiątych XIX w. batalią o panowanie nad wspomnianym Ulcinjem nasuwają się zresztą nieodparcie. W inspirującym wykładzie dziejów Czarnogóry, poświęconym okresowi od 1796 do 1878 r. zasygnalizował je czytelnie Branko Pavićević. Opisał on nie tylko, niezrealizowaną do końca, próbę poprowadzenia wtedy zsynchronizowanego uderzenia sił czarnogórskich na Podgoricę, Lesendro, Grmožur oraz Szkodrę z okolica, ale także wskazał na uzasadnianie ówczesnego planu opanowania stolicy tureckiego wilajetu szkoderskiego odwołaniami do średniowiecznej historii oraz na kwestię ich mityzowania ${ }^{41}$.

Planując udział w wojnie 1912 r., istotne znaczenie przypisywano w Czarnogórze także zajęciu, mocno już naówczas zalbanizowanej (bardziej niż Kosowo), Metochii (całej lub przynajmniej części). I tu znaczenie miały zarówno względy historyczne i polityczne, jak i argumenty strategiczne oraz ekonomiczne. Te ostatnie zasługują na podkreślenie. Otóż żyzność ziem Równiny Dukadzińskiej ${ }^{42}$ porównywać można z tą jaką charakteryzują się gleby na części terytorium Sandżaku Nowopazarskiego, Górnego Polimia czy równiny rozciągającej się między Szkodrą a Jeziorem Szkoderskim - dlatego właśnie Czarnogórze niezwykle zależało na kontrolowaniu tych terenów, mających zaopatrywać kraj w zboża ${ }^{43}$.

Wymienionym wyżej kwestiom historyczno-ideowo-politycznym też jednak należałoby się bliżej przyjrzeć. Czarnogórska pamięć o Metochii, akcentowanie w niej więzi z Pecią, Prizrenem czy Đakovica, a więc miejscami posiadającymi szczególne

${ }^{39} \mathrm{~W}$ niechęci tej przodowały oczywiście Austro-Węgry, które absolutnie nie chciały dopuścić do czarnogórskiego i serbskiego (w perspektywie - wspólnego) usadowienia się nad Adriatykiem. Pewną rezerwę w stosunku do czarnogórskich planów uczestnictwa w zbrojnym wystąpieniu przeciw Turcji, ukierunkowanym na terytorium zamieszkiwane przez Albańczyków, w których sprawy Czarnogóra angażowała się dość mocno w przededniu I wojny bałkańskiej, zachowywała nawet Rosja (zob. M. Tanty, Terytorialne aspiracje, s. 98). Imperium Romanowów miało wszakże powody do tego, by swojego głównego rywala w walce o pozycję na Bałkanach upatrywać nie w Turcji, lecz właśnie w Austro-Węgrzech.

${ }^{40}$ Zob. J. Rosochacki, Liga Albańska zawiqzana w Prizrenie (1878-1881) i jej walka w obronie niepodzielności terytorialnej obszaru zamieszkałego przez Albańczyków w ramach Imperium Osmańskiego, Poznań 1982 (maszynopis niepublikowanej pracy magisterskiej, napisanej pod kier. doc. dr. hab. W. Pająkowskiego), s. 99-103.

41 „Wraz ze znalezieniem się Ulcinja pod panowaniem czarnogórskim zaczęły narastać apetyty księcia Mikołaja. Zaczęły się w nim budzić historyczno-nostalgiczne tęsknoty za dawną średniowieczną chwałą. W świadomości Czarnogórców funkcjonowało odbieranie Szkodry, jako starej duklańskiej i zetskiej stolicy. Przetwarzało się to w mit. Budzenie narodowej świadomości w ludzie wiązało się z takimi mitami. Jeszcze w czasie swojego pobytu w Ulcinju książę Mikołaj zaczął formować specjalne jednostki mające maszerować na Szkodrę. [...] Wszystko zmierzało [do czasu] ku tryumfalnemu końcowi [...]"B. Pavićević, Sazdanje crnogorske nacionale države..., s. 285-286 (tłum. W. Szczepański).

${ }^{42} \mathrm{Tj}$. Metochii. Nazwę Dukađinska Ravnica spotyka się w serbszczyźnie z XIX i początku XX w.

${ }^{43}$ N. Rakočević, Crna Gora u balkanskom ratu, s. 19. 
znaczenie dla prawosławnej kultury serbskiej (czarnogórską traktować należy jako sytuującą się w obrębie tejże, mimo iż cerkiew w monarchii czarnogórskiej posiadała administracyjną odrębność od cerkwi serbskiej), jak też szereg aspektów wiążących się z wcieleniem na kilka lat części Metochii do Czarnogóry, to fenomeny zasługujące na zbadanie w osobnym studium.

Na dążność do podporządkowania Czarnogórze Metochii, co posiadało istotne znaczenie dla ugruntowania autorytetu monarchii Petroviciów - Njegošów w jej naznaczonym duchem rywalizacji partnerstwie z serbskimi Obrenoviciami i Karađorđeviciami (władający tą krainą Czarnogórcy stawali się depozytariuszami serbskiej „ziemi świętej”), wskazywała już, pochodzaca z 1867 r., pieśń pt. „Onamo, namo". Jaj autorem był, nie posiadający jeszcze wtedy tytułu królewskiego, Mikołaj Petrović Njegoš ${ }^{44}$. Pieśń ta, w której treści znajdują się słowa o powiązaniu ze sobą zbrojnych sił, którymi dysponują Serbowie (w znaczeniu: Serbowie z Serbii oraz okupowanych „ziem staroserbskich”, wraz z Czarnogórcami - braćmi jednych i drugich), co pozwolić ma na wyzwolenie m.in. południowo-metochijskiego Prizrena, funkcjonowała w Czarnogórze, także w latach 1912-1913 r., w roli nieoficjalnego narodowego hymnu, zagrzewającego do walki poddanych tego samego Mikołaja, którego skronie wieńczyła już wówczas korona królewska ${ }^{45}$. W hymnie „Onamo, namo”, wnikliwie zanalizowanym niedawno przez Bogusława Zielińskiego, w którego treści, oprócz pełnego serbskich, nemanjiciowskich symboli Prizrena, wspomina się także Dečani - rzeczywiście ważne, lecz i mityzowane duchowe centrum serbskości - oraz Jug (południe; serbskie/południowosłowiańskie ziemie położone na południe od granic wolnej Serbii, jakby czekające na swoich serbskich i czarnogórskich oswobodzicieli), zawarty jest jednoznaczny manifest czarnogórsko-serbskiego piemontyzmu ${ }^{46}$. Jak napisał B. Zieliński:

rozdźwięk między bohaterską i godną chwały przeszłością i niezadowalającym stanem współczesnym kreuje [wyrażony w hymnie - W.S.] program odnowienia średniowiecznej Serbii. [...] Czarnogórska doktryna dynastyczna - skonstatować można bowiem obecność w hymnie takiego przesłania - aktywuje rewindykacyjne przedsięwzięcia w stosunku do Prizrena, któremu przypisano w pieśni trojaką funkcję. Prizren jest bowiem, po pierwsze, synonimem serbskiego carstwa Duszana, jak też państwa duklańskiego Mihaila i Bodina. Wyzwolenie Prizrena spod tureckich rządów oznacza odbudowę Duszanowego carstwa. Po drugie, zrzucenie tureckiej władzy jest procesem obejmującym wyzwolenie: Serbii, Macedonii, Bośni i innych krajów; niemniej znaczenie Prizrena jako stolicy średniowiecznego państwa serbskiego jest kluczowe. Wyzwolenie Prizrena oznacza figuratywne odrodzenie państwa Duszana, gdyż carstwo stanie się wolne gdy oswobodzona zostanie jego stolica. Głównym podmiotem czarnogórskiej doktryny dynastycznej jest władca Czarnogóry - król Mikołaj. Czarnogóra i jej król zasługują na to żeby wyzwolić Carstwo Duszana. W końcu - histo-

44 Pieśń tę ogłoszono w cetyńskim kalendarzu „Orlić”. Jeszcze w tym samym roku przedrukowano ją w jednym z numerów serbskiej „Danicy”, ukazującej się w Nowym Sadzie (czyli poza ówczesnymi granicami Serbii).

45 N. Rakočević, Crna Gora u balkanskom ratu, s. 17.

46 B. Zielinski [Zieliński], Ideje crnogorske himnografije, [w:] Njegoševi dani 3. Zbornik radovaNikšić, 1-3. septembra 2010. Godine, uređ. odbor T. Bečanović, R. Glušica, Ž. Andrijašević, N. Jovović, Nikšić 2011, s. 22. 
ryczna ranga Prizrena była ogromna, gdyż miasto to jako stolica Duszanowego carstwa, z uwagi na swoje znaczenie polityczne, przemysłowe i handlowe, nosiło miano „serbskiego Konstantynopola”. [...] Restauracja carstwa Duszana, w które w hymnie włączona jest Czarnogóra, jest jednoznaczna $\mathrm{z}$ [realizacją - W.S.] programu tzw. serbskiego zjednoczenia narodowego czy też złączenia w jednym państwie wszystkich Serbów żyjących w krajach rządzonych przez Turków. [...] Hymn Mikołaja I traktować trzeba jako manifest czarnogórskiej polityki zjednoczeniowej, ściśle powiązanej z serbską ideologią zjednoczenia, której jądrem było odnowienie carstwa Duszana, z tym że Czarnogóra reprezentowała tu pełnoprawny podmiot, Czarnogórcy zaś „najautentyczniejszy substrat serbski” ${ }^{77}$.

Posiadanie określonych celów i ambicji politycznych oraz terytorialnych (implikujących również projekty geostrategiczne i gospodarcze) spowodowało, że Czarnogóra, mimo wątłych sił, pełna jednak wiary w sukces własny i sprzymierzeńców, we wsparcie Rosji oraz niemoc innych mocarstw europejskich ${ }^{48}$, jak też słabość bezpośredniego przeciwnika, czyli Turcji ${ }^{49}$, z entuzjazmem rozpoczęła działania wojenne na początku października 1912 r. W działaniach tych od razu skoncentro-

47 Tamże, s. 22-23 (tłum. W. Szczepański). Cytowane rozważania inspirowane były, jak sugerują zawarte w nich odwołania, tekstem jednego z najbardziej znanych współczesnych czarnogórskich historyków Živka M. Andrijaševića (por. artykuł tegoż pt. Ideološko-političko značenje pjesme „, Onamo, namo”, Stvaranje, I-V 1997, s. 174-177). Interesująca uwaga nt. znaczenia ewentualnego zajęcia Prizrena (i jak największej części Metochii) przy wydatnym udziale Czarnogórców (lub najlepiej samodzielnie przez nich) dla kształtowania dalszych relacji czarnogórsko-serbskich w duchu partnerstwa, a nie podległości mniejszej Czarnogóry w stosunku do większej Serbii - R. M. Raspopović, Diplomatija Crne Gore, s. 525 .

48 Niemoc tę akcentuje się m.in. w kontekście austrowęgiersko-rosyjskiego demarche skierowanego do państw-członków sojuszu bałkańskiego w dniu 8 X 1912 r. oraz nieskutecznych gróźb mocarstw, zapowiadających, iż nie uznają one zmian terytorialnych spowodowanych wojną sprzymierzeńców z Turcją, której gwałtownej porażki obawiano się we Wiedniu, Berlinie, Rzymie, Londynie, Paryżu, a nawet Petersburgu. Należy tu zaznaczyć, iż w Rosji nie od razu i nie całkiem jednoznacznie (przykład - wspomniana wyżej wspólna akcja dyplomatyczna z Wiedniem, która nie musiała być rosyjskim blefem) odstąpiono od strategii rywalizowania z Austro-Węgrami i Niemcami o wpływy w Turcji, mające wzrastać w rezultacie rosyjskiego pośredniczenia między nią a chrześcijańskimi państwami bałkańskimi w budowaniu pokojowych relacji. Na etapie budowy porozumień sojuszniczych na Bałkanach polityka rosyjska polegała na lawirowaniu między koncepcją żyrowania tychże i przygotowywania gruntu pod uderzenie na tureckiego ,kolosa na glinianych nogach” (istotna jest tu rola posła rosyjskiego w Belgradzie M. Hartwiga), a wstrzemięźliwym studzeniem nastrojów antytureckich (znaczenie inicjatyw dyplomatycznych przedstawiciela Rosji przy Wysokiej Porcie M. Czarykowa). Ostatecznie za korzystniejsze dla Rosji w jej ścieraniu się z Austro-Węgrami i Niemcami w zmaganiu o wpływy w Europie Południowo-Wschodniej uznano zawiązanie antytureckiego frontu państw południowosłowiańskich, zdolnego do wykreowania na Bałkanach nowego układu sił („,Bałkany dla państw bałkańskich"), skomponowanego ze wzmocnionych graczy regionalnych, otwartych na wpływy rosyjskie. Zob. H. Batowski, Państwa batkańskie, s. 177-180, 185-189; M. Dymarski, Konflikty, s. 243.

${ }^{49}$ W ocenie osobistej króla Czarnogóry Mikołaja I, jak również jego sojuszników, Turcja na początku drugiegodziesięcioleciaXXw.byłapaństwemsłabym(obnażyłatęsłabośćswojądrogąwojnawłosko-turecka) i zdezorganizowanym wewnętrznie. Trzeba było zatem ,[...] korzystać z chwili, w której reorganizacja wewnętrzna, wszczęta przezmłodoturków, nie osiągnęłajeszcze pokaźniejszych i trwalszych wyników. Jednym słowem, należało przystąpić do rozbijania imperium osmańskiego, zanim się ono tak wzmocni, że siły państw chrześcijańskich Półwyspu [Bałkańskiego] byłyby do tego za słabe” - H. Batowski, Państwa bałkańskie, s. 177. Szerzej o kondycji Turcji w pierwszych latach XX stulecia w studium: T. Wituch, Tureckie przemiany. Dzieje Turcji 1878-1923, Warszawa 1980. 
wano się na walce o Szkodrę z okolicą oraz na pochodzie do Metochii via Sandżak Nowopazarski.

Po osiagnięciu przedpola Szkodry przez Oddział Zetski księcia Daniły (wcześniej, maszerując z Podgoricy, zajął on Tuzi) i Nadmorski, dowodzony przez M. Martinovicia, siły czarnogórskie, mające za sobą wyczerpujące próby sforsowania ufortyfikowanych przez Turków wzgórz (przede wszystkim Taraboša) oraz przeprawianie się przez rzekę Bojanę i pobliskie błota, rozpoczęły oblężenie twierdzy szkoderskiej. Jesienią 1912 r. broniło jej nieco ponad 13,5 tys. tureckich żołnierzy (załoga twierdzy miała według wcześniejszych planów liczyć nawet 24 tys. ludzi). Pierwszy szturm planowano już na 24 X, ale ostatecznie przeprowadzono go w dniach 28-30 X 1912 r. Wzięcie Szkodry przeznaczono oddziałom księcia Daniły, atakującym miasto od północy, mimo iż pierwotnie mieli je od południa spróbować zajać żołnierze M. Martinovicia. Za zmianą rozkazu w tej materii stały względy ambicjonalne - zamiar króla Mikołaja I, aby sukces jego własnego syna podniósł prestiż Petroviciów, nadszarpnięty pierwszymi wojennymi tryumfami serbskimi. W końcówce października 1912 r. Szkodry nie udało się jednak zająć. Sytuację napastników komplikowały już od jakiegoś czasu złe i stale pogarszające się warunki atmosferyczne. Do wojsk obu wymienionych czarnogórskich Oddziałów, jednego atakującego Szkodrę i drugiego, udzielającego wsparcia oraz odcinającego to miasto od Adriatyku, dokooptowano siły Oddziału Wschodniego, dowodzone przez Janko Vukoticia, które przebiły się pod Szkodrę (dotarły tam 20 XI 1912 r.) przez góry (z Metochii, gdzie uprzednio walczyły) ${ }^{50}$. Wsparcia Czarnogórcom pod Szkodrą nie zdecydowali się za to udzielić jesienią 1912 r. Serbowie, skupiający się na prowadzeniu własnych operacji militarnych, mających na celu m.in. samodzielne opanowanie części ziem albańskich (włącznie z fragmentem pobrzeża) ${ }^{51}$. Oblężenie Szkodry nadal nie przynosiło efektów, a od kolejnego planu szturmu na nią (4 XII 1912) musieli Czarnogórcy odstapić pod naciskiem mocarstw. Turkom tymczasem udało się nawet wyprowadzić w grudniu 1912 r. kilka wypadów na pozycje czarnogórskie. Dodatkowo skomplikowali oni położenie części czarnogórskich wojsk przez wywołanie szerokiego rozlania się rzeki Bojany, której nurt zasilono wodami z Białego Drimu (oba cieki sztucznie połączono specjalnym kanałem $)^{52}$. Wznowione w 1913 r. próby zdobycia Szkodry, mimo wykrwawiania się Czarnogórców (szczególnie w natarciach z 7, 8 i 9 II 1913 r.) pod Tarabošem oraz pod - przejściowo nawet zdobytym - Wielkim Bardanjoltem, nie przyniosły pożądanego rezultatu. Miasto postanowiono w tej sytuacji pokonać ostrzałem artyleryjskim, zorganizowanym we współdziałaniu z Serbami. Za wsparcie sojusznika Czarnogórcy musieli zapłacić upokorzeniem oddania dowództwa Serbowi - gen. Petarowi Bojoviciowi. Ciagły ostrzał, a nawet kolejny szturm (30/31 III 1913 r.) nie doprowadziły do zdobycia Szkodry. Serbowie wycofali się z jej okolicy 11 IV 1913 r. Trwający na pozycjach oblężniczych Czarnogórcy, nie uczynili tego jed-

\footnotetext{
${ }^{50}$ M. Dymarski, Konflikty, s. 246-247.

51 Tamże, s. 247.

52 Tamże, s. 248.
} 
nak nawet na skutek potężnej presji mocarstw; także wtedy gdy presję tę wzmocniono obietnicami nawet 200 milionów franków kredytu na osuszenie okolic Jeziora Szkoderskiego i inne potrzeby gospodarcze Czarnogóry. Szkodra poddana została w końcu Czarnogórcom 22/23 IV 1913 r. przez jej obrońcę Esada-paszę tylko dlatego, że Turkom brakowało już żywności i amunicji. Radość Czarnogórców z wkroczenia 24 IV 1913 r. do miasta i górującej nad nim twierdzy, której klucz otrzymał książę Daniło, zamieniła się błyskawicznie w gorycz porażki, bowiem już w maju Czarnogóra zmuszona została do oddania losu miasta w ręce mocarstw, które miały podjąć decyzję o jej przyszłości ${ }^{53}$. W dniu $14 \mathrm{~V} 1912$ r. miejsce okupacyjnych wojsk czarnogórskich zajęły w Szkodrze międzynarodowe oddziały austrowęgiersko-brytyjsko-francusko-niemiecko-włoskie ${ }^{54}$. Sprawy były jednak przesądzone już wcześniej. Dnia 28 XI 1912 r. we Vlorze proklamowano powstanie państwa albańskiego ${ }^{55}$. Głównym sprzymierzeńcem i protektorem tego tworzącego się organizmu były Austro-Węgry, przeciwstawiające się czarnogórskim, serbskim i greckim pretensjom terytorialnym do obszarów byłych tureckich wilajetów szkoderskiego i janińskiego (co notabene stanowiło jeden z powodów kryzysu w relacjach Autro-Węgier z Rosją ${ }^{56}$ ). Państwowość albańska zyskała uznanie mocarstw już 20 XII 1912 r., zaś początek 1913 r. upłynął dyplomatom tychże m.in. na uzgadnianiu granic Albanii. Zakładano, iż obejmą one Szkodrę, mimo protestów składanych w tej sprawie przez Czarnogórców na ręce brytyjskiego premiera Edwarda Greya ${ }^{57}$. Wyrażona przez Rosję propozycja oddania Serbii metochijskiej Đakovicy, jako ekwiwalentu dla państw ,jugosłowiańskich" w sytuacji ewentualnej decyzji o przekazaniu Szkodry nie jej zdobywcom, czyli Czarnogórcom, lecz Albanii, jak też ostateczna decyzja międzynarodowej Konferencji Ambasadorów w tej sprawie z dnia 22 III 1913 r., de facto czyniła heroiczny wysiłek żołnierzy Mikołaja I wkładany w walkę o to miasto zupełnie pozbawionym sensu ${ }^{58}$. Za podobnie bezsensowne można zatem post factum uznać także odrzucenie przez Czarnogórę propozycji rekompensat za odstąpienie od Szkodry, przedłożonych jej przez mocarstwa na początku kwietnia $1913 \mathrm{r}$.

Lepiej niż w przypadku Szkodry skończyła się dla Czarnogórców batalia o przejęcie części Sandżaku Nowopazarskiego, położonego na północ od historycznego centrum czarnogórskiego państwa, a także Metochii. Na obszarach tych walczyły formacje Oddziału Wschodniego (jak już wspomniano przesunięte później pod Szkodrę). Znaczną część Sandżaku zajęli Czarnogórcy niemal bez walki w październiku 1912 r. Z opanowanego terytorium sandżackiego żołnierze J. Vukoticia prze-

\footnotetext{
53 Tamże, s. 271-272. Szerzej: G. Baliś, Kryzys skadarski 1913 roku, Studia Historyczne, 47, 2004, s. $47-59$.

${ }^{54}$ T. Rawski, Państwa, s. 89.

55 T. Czekalski, Baballaret e Kombit - charakterystyka i aktywność albańskich elit politycznych w toku I wojny bałkańskiej, Balcanica Posnaniensia. Acta et studia, t. XIX: Koegzystencja, s. 197-206.

${ }^{56}$ M.-Ž. Čalić, Istorija Jugoslavije, s. 82.

${ }^{57}$ M. Dymarski, Konflikty, s. 266-267.

58 Tamże, s. 267. Informacja o decyzji z 22 III 1913 r. za: R. M. Raspopović, Diplomatija Crne Gore, s. 567.
} 
suwali się do Metochii, gdzie czekało ich jednak spotkanie z wojskami serbskimi, zamierzającymi przyłączyć ten obszar do monarchii Karađorđeviciów. Czarnogórcy opanowali dwa ważne ośrodki miejskie Metochii, to jest Peć i Đakovicę, natomiast serbskim Wojskom Ibarskim udało się w drodze na Metochię obsadzić Nowy Pazar oraz Kosowską Mitrowicę. Na przełomie października i listopada Serbowie przemieścili swoje siły stamtąd pod wspomniane miasta metochijskie, przez co czarnogórsko-serbski ,,[...] braterski konflikt był bardzo prawdopodobny"59. Na szczęście dla obu stron doń nie doszło. W rezultacie w Metochii przez pewien czas funkcjonowały równolegle administracja czarnogórska i serbska ${ }^{60}$. Ostatecznie powojenna granica serbsko-czarnogórska wytyczona została tak, że obszar Metochii podzielono między Czarnogórę i Serbię, przyznając tej pierwszej Peć, a drugiej - wskutek wzmiankowanych już wyżej międzynarodowych targów o Szkodrę - Đakovicę, której pierwsze zdobycie stanowiło zasługę Czarnogórców. Położony w południowej części Metochii Prizren - ośrodek miejski o szczególnym potencjale, przewyższającym z pewnością Peć - znalazł się w granicach Serbii. Nie spełniły się zatem czarnogórskie marzenia o panowaniu nad miastem opiewanym przez Mikołaja I, ale po bezprecedensowym casusie Szkodry, nie było to chyba nawet porażką najdotkliwszą (Prizren dostał się chociaż pod panowanie sojuszników).

Bilans I wojny bałkańskiej dla Czarnogóry przedstawiał się tak, iż trudno jednoznacznie ocenić czy skończyła się ona dla tego państwa porażką czy zwycięstwem.

Formalnie oczywiście tym drugim. Czarnogóra, mimo przegranej kampanii o panowanie nad Szkodrą i okolicą oraz wymuszonego rozwojem wydarzeń frontowych (i międzynarodową korektą w sprawie Đakovicy) podziału Metochii na część czarnogórską i serbską, opanowawszy część tej krainy, południową część Sandżaku Nowopazarskiego (zawierająca obszar dawnej tureckiej nahiji plavsko-gusinjskiej), jak również skrawki ziemi pod samą Podgoricą, powiększyła swoje terytorium z posiadanych $9335 \mathrm{~km}^{2}$ do $14254 \mathrm{~km}^{2} 61$.

Takie powiększenie terytorium najmniejszego $\mathrm{z}$ bałkańskich państw uznać należy za naprawdę znaczące. Niezbyt ludnej i ubogiej Czarnogórze niełatwo było wręcz zapewnić sprawną administracją na tak rozległym obszarze, a i opracowanie jakiejś przemyślanej, spójnej koncepcji gospodarczego wykorzystania pozyskanego potencjału, należało do zadań bardzo trudnych. Inna sprawa, że państwo czarnogórskie w nowych granicach, których międzynarodowe uznanie wynegocjowane zostało w 1913 r., przetrwało bardzo krótko; wszystko przekształciło się bowiem w niepożądanym dla Czarnogóry kierunku podczas i w rezultacie Wielkiej Wojny, która zaczęła trawić Bałkany już latem 1914 r.

Pozytywnym dla Czarnogóry rezultatom I wojny bałkańskiej towarzyszyła też gorycz porażek. Złożyły się na nie zarówno iście pyrrusowe zwycięstwa, zamieniające się w wielkie przegrane (Szkodra!), lub też w mniejsze porażki (konieczność po-

\footnotetext{
${ }^{59}$ M. Dymarski, Konflikty, s. 246.

${ }^{60}$ Tamże.

${ }^{61}$ H. Batowski, Państwa batkańskie, s. 224.
} 
czynienia ustępstw na rzecz Serbii w Metochii), ale także, a może przede wszystkim, rozmiary poniesionych strat ludzkich i konsekwencje ekonomiczne uczestnictwa w wojnie. Za M. Dymarskim przypomnieć należy, iż Czarnogóra poniosła w trakcie I wojny bałkańskiej -

[...] relatywnie do wielkości swojej armii, największe straty. Spośród 35600 zmobilizowanych, zabitych zostało 2430 żołnierzy, 406 zmarło w wyniku ran i chorób, a 6603 żołnierzy było rannych, co daje łącznie liczbę 9439 , blisko $1 \frac{1}{3}$ stanu czarnogórskiej armii ${ }^{62}$.

Gospodarcze konsekwencje udziału w wojnie odczuwane przez Czarnogórę w okresie od jej zakończenia do wybuchu I wojny światowej, określić można z kolei jednym słowem: ruina. Bliższa ich analiza wymagałaby osobnego opracowania.

Również polityczne cele jakie przyświecały królowi Mikołajowi I w momencie decydowania się na walkę u boku Serbów i pozostałych bałkańskich sprzymierzeńców z Turcją, z którą w przededniu wywołania I wojny bałkańskiej państwo Petroviciów-Njegošów posiadało stosunki co najmniej poprawne ${ }^{63}$, nie zostały zrealizowane w sposób, który przynieść mógłby Czarnogórze długofalowe profity w materii umocnienia jej autorytetu międzynarodowego, czy też - na co już wskazywano wyżej - osiągnięcia takiej regionalnej pozycji politycznej, która zapewnić mogłaby podmiotową a nie przedmiotową rolę małej monarchii w konstruowaniu wraz z Serbią wielkiego projektu jugosłowiańskiego.

Czarnogóra, choć powiększona i kontrolująca część obszarów posiadających wyjątkowe znaczenie także dla Serbii (metochijska Peć - siedziba serbskiego patriarchatu prawosławnego, część Sandżaku Nowopazarskiego), wskutek wojennych strat w ludziach, uzbrojeniu i nakładach finansowych, była państwem słabym, nie dysponującym potencjałem, które czyniło by zeń partnera dla większej Serbii. Monarchia Karađorđeviciów, dowartościowywana poparciem Rosji, zdającej sobie sprawę z tego, że to serbski, a nie czarnogórski potencjał może stanowić punkt oparcia dla realizacji dalekosiężnych zamierzeń politycznych i gospodarczych caratu na Bałkanach, czuła się, mimo utracenia swoich zdobyczy w Albanii, zwycięzcą I wojny bałkańskiej (a potem i wojny międzysojuszniczej, w której pokonana i pozbawiona imperialnych złudzeń została Bułgaria) oraz niekwestionowanym politycznym liderem całej Słowiańszczyzny Południowej. Zajmując taką pozycję nie zakładała ona w ogóle możliwości ustępowania Czarnogórcom w czymkolwiek (ten rys postawy serbskiej zauważyć można było już w warunkach dyktowanych Czarnogórze pod Szkodrą podczas wspólnego oblegania tego miasta w pierwszych miesiącach 1912 r.), lecz jedynie oferowała im możliwość odegrania roli pomocnika w dziele jednoczenia świata jugosłowiańskiego pod hegemonią serbską ${ }^{64}$. Ambitny, lecz nie mający realnie na czym

62 M. Dymarski, Aspekty ekonomiczne i spoteczne, s. 226.

63 Tamże, s. 228-229.

${ }^{64}$ Historycy toczą spory co do rzeczywistego oblicza serbskich koncepcji zjednoczenia obszaru jugosłowiańskiego - zarówno tej z drugiej połowy XIX, jak i tej z pierwszych kilkunastu lat XX w., upatrując w nich już to szczerego jugoslawizmu, już to kamuflażu dla koncepcji nacjonalistycznej i wielkoserb- 
oprzeć swoich wielkich planów „stary król” Mikołaj I przestawał być dla serbskiego dworu i Nikoli Pašicia politycznym partnerem, a zaczynał być kimś, kogo pożyteczne zaangażowania w ten czy ów koncept można wykorzystać, po to by następnie bezlitośnie go ograć. $Z$ całym dramatyzmem potwierdził to rozwój relacji serbskoczarnogórskich w trakcie I wojny światowej (nieprzypadkowy przecież, lecz współkreowany przez władze serbskie i jego, nie zawsze występujących od razu w sposób jawny, sojuszników z Czarnogóry, takich jak chociażby Andrija Radović czy Janko Spasojević ${ }^{65}$ ).

Nie miejsce w niniejszych rozważaniach na wywody spekulacyjne, niemniej warto poświęcić w nich uwagę jeszcze jednej kwestii, niejako sygnalizując w ten sposób pewien trop interpretacyjny, którego wnikliwsze podjęcie wymagałoby jednak szerszych badań. Historyk, podejmując się nie tylko opisywania, ale i interpretacji przeszłości, posiada wszakże prawo do zwracania uwagi, w oparciu o dostępną mu wiedzę, którą niekoniecznie mieli możliwość posiąść bohaterzy opisywanych przez niego wydarzeń, na projekty polityczne niespożytkowane w danym czasie w pełni, czy wręcz definitywnie zarzucone.

$\mathrm{Ku}$ pewnemu ciekawemu wątkowi, wiążącemu się z rozpatrywanymi tu zagadnieniami, który umyka niekiedy uwadze naszych historyków, prowadzi krótki cytat z pochodzącej z 1938 r. rozprawy Henryka Batowskiego, poświęconej państwom bałkańskim w okresie od początku XIX w. do 1923 r.:

Poza [...] czterema sprzymierzonymi państwami chrześcijańskimi i Turcją istniał na Półwyspie [Bałkańskim] jeszcze jeden czynnik, który mógł znacznie zaważyć na rozwoju wypadków: naród albański. Zlekceważony przez młodoturków, a niewiele lepiej oceniony przez państwa chrześcijańskie, czynnik ten jednak chwilowo odniósł pokaźny sukces, który, gdyby nie natychmiastowy wybuch wojny [bałkańskiej w 1912 r.], mógł był z gruntu zmienić w ciagu lat paru sytuację na Bałkanach ${ }^{66}$.

Mowa tu oczywiście, co zresztą autor w dalszych słowach precyzyjnie wyjaśnia, o powstaniach albańskich z lat 1910-1912. Doprowadziły one do pogłębienia świadomości więzi Albańczyków z różnych wilajetów osmańskiej Turcji. W wymiarze militarnym i polityczno-administracyjnym ich skutkiem było zaś m.in. osiagnięcie tak ważkie, jak przejściowe opanowanie latem 1912 r. Skopia - ówczesnej stolicy wielkiego wilajetu kosowskiego ${ }^{67}$.

Warto pamiętać o tym, że zarówno Czarnogóra, jak i Serbia, posiadały stosunkowo znaczący dorobek w zakresie takiego ingerowania w sprawy Albańczyków,

skiej. Zob. m.in.: W. Szulc, Przemiany gospodarcze i społeczne w Jugosławii w okresie międzywojennym 1918-1941, Poznań 1980, s. 14-22; D. Agičić, Tajna politika Srbije u XIX stoljeću, Zagreb 1994; Velika Srbija: istina, zablude, zloupotrebe, ured. V. Krestić, M. Nedić, Beograd 2003; M.-Ž. Čalić, Istorija Jugoslavije, s. 21-99.

${ }^{65}$ Zob. Ž. M. Andrijašević, Crnogorci protiv Crne Gore, na: http://www.montenegro.org.au/cgne prijatelji.html (dostęp 6 I 2012); Š. Rastoder, Politika svršenog čina, s. 199-235.

${ }^{66} \mathrm{H}$. Batowski, Państwa bałkańskie, s. 184.

${ }^{67}$ Do zajęcia Skopia przez Albańczyków doszło 13 VIII 1912 r. - T. Czekalski, Baballaret e Kombit, s. 200 . 
które pozwalało państwom tym wykorzystywać, w sposób dla nich korzystny, wewnątrzalbańskie rozdźwięki, powodowane różnicami wyznań religijnych oraz kalkulacji politycznych ${ }^{68}$. W szczęśliwym splocie okoliczności, Czarnogórcy zawierać mogli różnego rodzaju porozumienia z katolicką społecznością zamieszkującą Szkodrę i okolice, mimo, iż liderzy tejże społeczności uznawali za jej głównego protektora monarchów austrowęgierskiego i włoskiego. Na początku XX w. nadzieje na to, że na północy ziem rdzennie albańskich powstanie niezależne od Turcji i Albańczykówmuzułmanów, kadłubowe państwo pod przywództwem katolickich Mirditów, żywione były przez elity czarnogórskie i serbskie całkiem na poważnie. Państwo to (czy raczej państewko) mogłoby, jak zakładano, mimo sympatii prohabsburskich i prowłoskich posiadanych przez jego mirdickich przywódców, czynić określone cesje polityczne i gospodarcze na rzecz chrześcijańskich, słowiańskich sąsiadów. Naturalnie nie bez własnego interesu, lecz w zamian za poparcie udzielane północno-albańskim katolikom w ich stosunkach z Albańczykami-muzułmanami. Stosunki te były wszakże naówczas z reguły antagonistyczne, mimo angażowania się części katolickiej elity albańskiej z wilajetu szkoderskiego i diaspory w ruch propagujący idee albańskiego zjednoczenia narodowego ${ }^{69}$.

$\mathrm{Z}$ czarnogórsko-serbskiego duetu, w dobie powstań albańskich przeciw młodoturkom, a więc w przededniu wybuchu I wojny bałkańskiej, lepsze rozpoznanie odnośnie tego, co działo się w relacjach wewnątrzalbańskich, jak też silniejsze argumenty za ewentualnym wiązaniem ze sobą północno-albańskich katolików, posiadała Czarnogóra. W dużej mierze stanowiło to zasługę konsulatu Królestwa Czarnogóry w Szkodrze, kierowanego w tych czasach najpierw przez Petara Plamenca, a następnie przez Dušana Gregovicia ${ }^{70}$. Pamiętać należy również o monitorowaniu przez Czarnogórców działań, które podejmowali albańscy emigranci w Nikšiciu, Cetyni i Podgoricy (szczególnie tych z końca 1910 r. oraz z lat 1911-1912) oraz w innych ośrodkach czarnogórskich, w których w dobie antytureckiej rebelii Albańczyków powstawały m.in. agendy Komitetu Albańskiego Ismaila Qemala ${ }^{71}$. Czarnogórców

${ }^{68}$ R. M. Raspopović, Diplomatija Crne Gore, s. 524-529 ; 550-560 ; W. Szczepański, Serbowie a Albańczycy w latach 1878-1918, Poznań 2005 ( nieopublikowana rozprawa doktorska, napisana pod kierunkiem dr. hab. W. Szulca, prof. UAM). Szerzej o relacjach czarnogórsko-albańskich w tym okresie: I. Bicaj, Marrëdhëniet shqiptaro-malazeze (1881-1914), Prishtinë 2003, M. Dymarski, Pólnocna Albania w polityce władcy Czarnogóry Mikołaja I Petrovicia 1878-1913, [w:] Polska leży na Zachodzie. Studia z dziejów Polski i Europy dedykowane Profesor Teresie Kulak, Toruń 2011, s. 209-216. Zob. również edycję źródeł: N. Nika, Përmbledhje dokumentesh mbi kryengritjet shqiptare (1910-1912), Prishtinë 2003.

${ }^{69}$ Szerzej o tym w: W. Szczepański, Znaczenie katolicyzmu dla odrodzenia narodowego Albańczyków i budowy przez nich własnego państwa (druga połowa XIX - poczatek XX w.), Studia z Dziejów Rosji i Europy Środkowo-Wschodniej, t. XLII, 2007, s. 5-15.

${ }^{70}$ Tenże, Serbowie a Albańczycy... (zob. informacje zawarte w podrozdziale 3.1. rozdziału 3. cytowanej rozprawy).

${ }^{71}$ Tamże. Zob. również: M. Dymarski, Polityczne i kulturowe relacje czarnogórsko-albańskie w XX i XXI wieku, [w:] Międzycywilizacyjny dialog w świecie słowiańskim w XX i XXI wieku, pod red. I. Stawowy-Kawki, Kraków 2012, s. 216-219. Najważniejszym kierunkiem migracji Albańczyków, uchodzących w obawie przed represjami ze strony Turków, była Czarnogóra. Część Albańczyków docierających do Czarnogóry osiedlana była przez czarnogórskie władzę w Nikšiciu. Wielu z nich jed- 
niejednokrotnie oskarżano też na forum międzynarodowym o podsycanie nastrojów antytureckich w Albańczykach z regionów Mirdita i Malësia oraz o dozbrajanie tamtejszych powstańczych oddziałów, a nawet o prowadzenie rokowań z ważnymi liderami albańskimi Bajramem Currim i Isą Boletinim, posiadającymi wpływy wykraczające poza północno-albański obszar działań irredentystycznych. Nie były to zarzuty bezpodstawne ${ }^{72}$.

Dysponując takimi podwalinami pod rozwój czy wręcz intensyfikację związków państwa czarnogórskiego z częścią Albańczyków, skłonnych sprzyjać Czarnogórcom, warto było zaangażować potrzebne środki w celu uczynienia ich sojusznikami królestwa Petroviciów-Njegošów w trakcie I wojny bałkańskiej. Wpływy wśród północnoalbańskich katolików stanowić mogły bowiem nie tylko potencjalny atut w momencie podjęcia zbrojnej konfrontacji z Turcją, która musiałaby mieć w takich okolicznościach na celu usunięcie jej administracji i obsady wojskowej ze Szkodry oraz okolic tego miasta bez jednoczesnego zadrażniania relacji z tamtejszymi Albańczykami. Współpraca Czarnogórców z Albańczykami z regionu szkoderskiego mogłaby poza tym stanowić kartę przetargową w przyszłych negocjacjach czarnogórsko-serbskich, w których decydowano by o roli Czarnogóry w jugosłowiańskim procesie zjednoczeniowym, a także w porozumiewaniu się z Czarnogórców z dyplomatami austrowęgierskimi i włoskimi (oraz, w mniejszym stopniu, z reprezentantami pozostałych europejskich mocarstw). Odpowiednie, a przede wszystkim w porę podjęte, starania

nak aktywnie funkcjonowało także w bliskich albańskiej Malësii okolicach Podgoricy czy nawet w samej Cetyni. Czasopisma czarnogórskie i określone komórki rządowe poświęcały emigrantom albańskim bardzo dużo uwagi. Problem z zainteresowaniem śledzony był jednak również przez Serbów. W grudniu 1910 roku konsul Serbii w Skopiu Jovan M. Jovanović opisywał swojemu przełożonemu z Belgradu Milovanovi Milovanoviciowi ucieczkę „w góry, a stamtąd do Czarnogóry” jednego z albańskich dowódców powstańczych Sulejmana Batushy, któremu towarzyszyło „150 znanych Albańczyków” (viđenih Arbanasa). Zob. Jovan M. Jovanović - Gospodinu dr Milovanu D. Milovanoviću Ministru inostranih dela - Beograd, Skopie, 9 XII 1910, [w:] B. Peruničić, Svedočanstvo o Kosovu 1901-1913, Beograd 1988, s. 492; Generalni konsul Jovan M. Jovanović - Ministarstvu inostranih dela, Beograd, Skopie 9 XII 1910, tamże, s. 493; M. Vojvodić, Prilike na Kosovu i Metohiji i politika Srbije 1881-1912, [w:] tenże, Srbija i balkansko pitanje (1875-1914), Novi Sad 2000, s. 55-56.

72 W oficjalnych wystąpieniach czarnogórskich polityków z końca 1910 oraz z 1911 r. narzekano na nieszczelność granic państwa, przez które przenikały w głąb kraju już od grudnia 1910 r. między innymi grupy uzbrojonych podkomendnych I. Boletiniego (zob.: Crna Gora i ustanak, Beogradske novine, br. 79, 21 III 1911, s. 1). W Cetyni podkreślano wówczas w jednoznaczny sposób „prawidłowy stosunek” (korektno ponašanje) Czarnogóry do Turcji, czyli stosując dzisiejszą nomenklaturę - stanie przez Czarnogórę na fundamencie politycznej poprawności w jej stosunkach z państwem osmańskim. W miarę słabnięcia Turcji, słabła jednak również czarnogórska motywacja do zachowywania rzeczonej poprawności. Zręcznie prowadzoną polityką, czarnogórski dwór usiłował pozyskać szczepowych przywódców północnoalbańskich. O podejmowaniu tego rodzaju wysiłków świadczyć mogła m.in. misja specjalnego przedstawiciela czarnogórskiego dworu królewskiego pomiędzy Albańczykami, w której albańskim liderom, wcześniej jakoby niemile widzianym w Cetyni (I. Boletiniemu i B. Curriemu), proponowano przenosiny do Czarnogóry i koordynowanie stamtąd napadów na Turków, zob.: Ministarstvo vojno Kraljevine Srbije - Beograd Ministru inostranih dela Kraljevine Srbije - Beograd, Beograd 6 VI 1912, [w:] Dokumenti o spoljnoj politici Kraljevine Srbije 1903-1914, kn. V, 1: 1/14.januar - 14/27. juli 1912., prir. M. Vojvodić, ured. R. Samardžić, Beograd 1984., s. 812-813. 
o to, by w rozgrywkę polityczno-militarną lat 1912-1913 wejść zabezpieczonym różnymi alternatywnymi porozumieniami z liderami północno-albańskimi, stawiającymi Czarnogórę na korzystniejszej pozycji względem Serbii - potrzebującej Czarnogóry oraz wpływów w zamieszkiwanym przez Albańczyków regionie nadadriatyckim mogły pomóc Czarnogórze w zabieganiu o zachowanie w niedalekiej przyszłości bardziej satysfakcjonującej pozycji w strukturze jugosłowiańskiego organizmu państwowego, którego przyszłego wyłonienia już wówczas się spodziewano. W przypadku fiaska projektu jugosłowiańskiego, układy z albańskimi sąsiadami zawsze stanowiłyby dla Czarnogóry argument $w$ zabiegach o zachowanie niezależności państwowej czy też w ewentualnych staraniach wolnego czarnogórskiego królestwa o zawarcie strategicznych porozumień z Serbią oraz z Albanią. Zamiast tego, w latach 1914-1918 Czarnogórze przyszło jednakże, w roli ogrywanego przez Serbię sojusznika, stoczyć wyłącznie - by użyć tu określenia z tytułu ciekawej książki Dragoljuba Živojinovicia - skazaną na porażkę ,walkę o przetrwanie"73.

\title{
THE POLITICAL AND TERRITORIAL OBJECTIVES OF THE KINGDOM OF MONTENEGRO ON THE EVE OF AND DURING THE FIRST BALKAN WAR
}

\author{
Summary
}

Montenegro, the smallest of the Balkan states in the beginning of the 20th century, was especially interested in creating an anti-Turkish alliance. It aimed at attaching the fertile lands of Sandžak of Novi Pazar, Metohija and Shkodër. Finally, as a result of the I Balkan War, it managed to achieve the first two aims, only if partially, because it had to share those lands with Serbia.

Montenegro did not manage to take over control of Shkodër and the surroundings inhabited mainly by Albanians. There were many reasons why Montenegro did not manage to realize its territorial aspirations:

- the poor financial condition of the state of Montenegro on the eve of the war, which prevented them from gaining a strong position in the Balkan alliance and made a success in its military actions dependent on the allies, especially on Serbia; Shkodër;

- the detrimental pressure exerted by king Nicolas I to fight at any cost for the control over

- a conflict of interest and mistakes made by the Montenegro authorities in developing their relations with Serbia, which weighed later on the relations between Montenegro and Serbia in the period between the Balkan wars and the First World War, as well as at the time when Yugoslavia began to unite around the idea of building the common state.

- not appreciating to a sufficient degree the significance of the Albanian problem and not using the possession of the North Albanian lands as a bargaining chip in the relations with neighbors, particularly with Serbia.

${ }^{73}$ D. Živojinović, Crna Gora u borbi za opstanak 1914-1922., Beograd 1996. 